Volume 2 Issue 1, March 2018: pp. 354-370. Copyright (c) 2018 HOLREV. Faculty of Law, Halu Oleo University, Kendari, Southeast Sulawesi, Indonesia. ISSN: 2548-1762 | e-ISSN: 2548-1754. Open Access at: http://ojs.uho.ac.id/index.php/holrev/

Halu Oleo Law Review is licensed under a Creative Commons Attribution 4.0 International License, which permits unrestricted use, distribution, and reproduction in any medium, provided the original work is properly cited.

\title{
Hubungan Kerja dalam Perspektif HAM, Ekonomi, dan Pembangunan
}

\author{
Labor Relation on Perspectives of Human Rights, Economics and \\ Development
}

\author{
Joko Ismono \\ Fakultas Hukum Universitas Wijaya Putra Surabaya \\ E-mail: jack.fhua@gmail.com
}

\begin{abstract}
The article aimed at analysing the concept of work relationship by using human rights, economic, and development perspectives. The parties in the industrial relationship consists of workers, employers, and government have the different interests. The disputes arising within industrial relationship primarily caused by the dispute of the parties solely perceive the problem by own perspective. Basically, integral understanding toward work relationship become the basis of a completion of comprehensively dispute of work relationship.
\end{abstract}

Keyword: development, economic, human rights, work relationship.

\begin{abstract}
Abstrak: Tujuan makalah ini adalah untuk menganalisis konsep hubungan kerja dalam perspektif HAM, ekonomi, dan pembangunan. Para pihak dalam hubungan industrial yang terdiri dari pekerja, pengusaha, dan pemerintah memiliki kepentingan yang berbeda. Timbulnya perselisihan hubungan industrial pada dasarnya disebabkan karena para pihak yang bersengketa melihat suatu permasalahan hanya dari sudut pandangnya sendiri. Pemahamanyang utuh tentang hubungan kerja menjadi dasar dari suatu penyelesaian perselisihan hubungan industrial yang komprehensif.
\end{abstract}

Kata kunci: ekonomi, hubungan kerja, pembangunan, perspektif HAM.

\section{PENDAHULUAN}

Hubungan kerja adalah hubungan hukum yang terjalin antara pekerja dengan pengusaha selaku pemberi kerja berdasarkan perjanjian kerja dengan unsur-unsur pembentuknya yang terdiri dari unsur pekerjaan, unsur upah, dan unsur perintah. Hubungan kerja dapat 
dilihat dari 3 (tiga) perspektif. Ketiga perspektif tersebut mewakili kepentingan yang berbeda dari para pihak yang terlibat dalam suatu hubungan industrial. Para pihak yang memiliki perbedaan kepentingan dalam hubungan industrial tersebut adalah pekerja, pengusaha, dan pemerintah.

Dalam perspektif pekerja, fungsi hukum ketenagakerjaan adalah untuk melindungi pekerja dari eksploitasi dan diskriminasi yang mungkin terjadi dalam suatu hubungan kerja. Dalam perspektif pengusaha, fungsi hukum ketenagakerjaan adalah untuk mencapai tujuan ekonomi berupa keuntungan atau profit bagi perusahaan. Sedangkan dalam perspektif pemerintah, fungsi hukum ketenagakerjaan adalah untuk menciptakan hubungan industrial yang harmonis demi terwujudnya kemajuan dunia usaha dan kesejahteraan pekerja.

Perbedaan pandangan mengenai peran hukum ketenagakerjaan dalam perspektif pekerja dan pengusaha dikemukakan oleh Wheelwright sebagaimana paparan berikut

It is useful to consider two dramatically different views about the role of law in labour relations. In one view the law must actively protect workers from exploitation and discrimination, on the other view the goal is competitiveness facilitated by the free play of market forces means that the law should interfere as little as possible in the labour relations. ${ }^{1}$

\section{ANALISIS DAN PEMBAHASAN}

\section{Hubungan Kerja dalam Perspektif HAM}

Perspektif pekerja dalam melihat hubungan kerja adalah perspektif hak asasi manusia (HAM). Dalam perspektif pekerja, pemenuhan hak asasi manusia hendaknya diberikan kepada semua pekerja tanpa membedakan pekerja dengan hubungan kerja tetap atau pekerja dengan fleksibilitas hubungan kerja berdasarkan prinsip non diskriminasi. Perlindungan hukum bagi pekerja diberikan karena keamanan dan keberlangsungan kerja menjadi terancam akibat diterapkannya fleksibilitas hubungan kerja.

Hak asasi manusia adalah hak dasar atau hak pokok yang dibawa manusia sejak lahir sebagai anugerah Tuhan. Hak asasi manusia secara harfiah berarti hak-hak yang dimiliki seseorang semata-semata karena ia adalah seorang manusia. Hak asasi manusia merupakan hak yang dimiliki oleh setiap manusia setara atau sama seperti yang miliki oleh orang lain. Hak asasi manusia merupakan hak yang tidak dapat dicabut. Hak asasi manusia

1 Wheelwright, Karen, Labour Law, Sydney: Butterworths, 1999, hlm. 7. 
adalah hak yang bersifat universal dalam arti semua manusia adalah pemegang hak asasi manusia. Hak asasi manusia menjadi dasar bagi lahirnya hak-hak yang lain.

Bill of Rights di Amerika dan Declaration of The Rights of Man and Citizen di Perancis yang disusun pada akhir abad ke delapan belas adalah dokumen yang pertama kali memuat daftar hak asasi manusia (HAM) Dokumen tersebut lahir sebagai reaksi terhadap represi tirani penguasa yang melanggar hak kebebasan individual. Dalam bidang hukum ketenagakerjaan, tahapan penting dalam perkembangan hak-hak ketenagakerjaan adalah terbentuknya International Labour Office di tahun 1919, sebagai cikal bakal dari International Labour Organizations (ILO), dengan tugas untuk menyusun standar perburuhan internasional (international labour standards). Meskipun terdapat pandangan skeptis yang menilai bahwa langkah tersebut diambil untuk melindungi kepentingan perusahaan dari negara-negara maju dalam persaingan dengan perusahaan yang didirikan di negara-negara dengan standar perburuhan yang rendah, akan tetapi rintisan dari pengakuan hak-hak perburuhan di lingkup internasional sudah dimulai.

Pada tahun 1948 Majelis Umum PBB mendeklarasikan Universal Declaration of Human Rights, yang selanjutnya ditindaklanjuti dengan pembentukan International Covenant on Civil and Political Rights (ICCPR) dan International Covenant on Economic, Social, and Cultural Rights (ICESCR) pada tahun 1966. Di bidang ketenagakerjaan, dibentuklah International Labour Organizations (ILO) yang melanjutkan tugas untuk menyusun dan mempromosikan standar perburuhan internasional.

Hak asasi manusia (HAM) umumnya dibagi menjadi dua kelompok yaitu Hak Sipil dan Politik (Civil and Political Rights) dan Hak Ekonomi, Sosial, dan Budaya (Economic, Social, and Cultural Rights). Hak sipil dan politik adalah hak yang berkaitan dengan kebebasan individu sebagai warga dari suatu negara yang demokratis, yang meliputi perlindungan dari tirani penguasa yang sewenang-wenang, persamaan di hadapan hukum, kebebasan untuk memilih dan dipilih dalam proses demokrasi, kebebasan berpendapat, dan seterusnya. Sedangkan hak ekonomi, sosial, dan budaya adalah hak yang berkaitan dengan hak individu dalam pemenuhan kebutuhan hidup, yang meliputi hak atas pekerjaan, hak atas pemeliharaan kesehatan, hak atas lingkungan yang sehat, hak atas jaminan sosial, dan seterusnya. Hak ekonomi, sosial, dan budaya mempunyai relevansi yang sangat besar dengan hukum ketenagakerjaan, sedangkan bentuk hak sipil dan politik yang ada relevansinya dengan hukum ketenagakerjaan di antaranya adalah hak berserikat bagi pekerja hak mogok, dan hak untuk tidak mendapatkan diskriminasi di tempat kerja. 
Dua jenis hak sipil dan politik yang relevan dengan hubungan kerja adalah hak berserikat bagi pekerja dan hak non diskriminasi. Hak berserikat termuat di dalam Article 23(4) Universal Declaration of Human Rights dan Article 22 International Covenant on Civil and Political Rights (ICCPR). ICCPR memberikan penjelasan secara umum tentang hak berserikat sebagai berikut:

Everyone has the right to freedom of peaceful assembly and to freedom of association with others, including the right to form and join trade unions for the protection of his interest.

Hak non diskriminasi termuat dalam hampir semua dokumen tentang HAM. Article 26 ICCPR memuat hak non diskriminasi sebagai berikut:

All persons are equal before the law and are entitled without any discrimination to the equal protection of the law. In this respect, the law shall prohibit any discrimination and guarantee to all persons equal and effective protection againts discrimination on any gound such as race, colour, sex, religion, language, political or other opinion, national or social origin, property, birth, or other status.

Jenis hak sosial, ekonomi, dan budaya yang relevan dengan hubungan kerja adalah hak atas pekerjaan, hak atas upah, dan hak atas kesehatan dan keselamatan kerja. Hak atas pekerjaan termuat dalam Article 23(1) Universal Declaration of Human Rights dan Article 6 International Covenant on Economic, Social, and Cultural Rights (ICESCR). Hak atas upah yang layak bagi pekerja termuat dalam Article 23(3) Universal Declaration of Human Rights dan Article 7 International Covenant on Economic, Social, and Cultural Rights (ICESCR).

Penghargaan terhadap hak asasi manusia (HAM) di tempat kerja termuat dalam konvensi dasar International Labour Organizations (ILO). Konvensi dasar ILO mengenai hak-hak dasar di tempat kerja terdiri dari 8 (delapan) konvensi ILO yang terbagi dalam 4 (empat) kelompok sebagai berikut:

a. Kebebasan Berserikat (Konvensi ILO Nomor 87 dan Nomor 98).

b. Penghapusan Diskriminasi (Konvensi ILO Nomor 100 dan Nomor 111).

c. Penghapusan Kerja Paksa (Konvensi ILO Nomor 29 dan Nomor 105).

d. Penghapusan Pekerja Anak (Konvensi ILO Nomor 138 dan Nomor 182).

Perlindungan terhadap hak asasi manusia (HAM) pada mulanya dikenal dalam teori kontrak sosial yang dikemukakan oleh J.J. Rousseau. Berdasarkan teori kontrak sosial maka hak-hak yang dimiliki oleh setiap individu diserahkan kepada negara berdasarkan kehendak bebas. Tugas negara adalah memberikan perlindungan kepada setiap warga 
negara apabila terjadi pelanggaran terhadap hak-hak warga negara untuk mewujudkan ketertiban dan keadilan.

Penghormatan terhadap HAM merupakan salah satu karakteristik dalam konsep negara hukum. Konsep negara hukum terdapat dalam penjelasan umum UUD 1945 yang menyatakan bahwa Indonesia adalah negara yang berdasarkan atas hukum (rechtsstaat) tidak berdasarkan atas kekuasaan (machsstaat). Konsep tersebut dimuat lagi dalam Pasal 1 ayat (3) amandemen ke-3 (tiga) UUD 1945 yang menyatakan bahwa negara Indonesia adalah negara hukum.

Konsep negara hukum memiliki karakteristik kekuasaan negara dibatasi oleh hukum, adanya penghormatan terhadap hak-hak individu, dan keberadaan peradilan yang bebas dan tidak memihak. Negara hukum adalah negara yang menempatkan hukum sebagai dasar dari pelaksanaan kekuasaan negara dan penyelenggara kekuasaan negara dalam segala bentuknya dilakukan di bawah kekuasaan hukum.

The rule of law adalah konsep negara hukum yang dikemukakan oleh Dicey dengan karakteristik sebagai berikut:

a. Kekuasaan negara tidak dijalankan secara sewenang-wenang melainkan dibatasi oleh hukum (supremacy of law).

b. Setiap warga negara mempunyai kedudukan yang setara di hadapan hukum (equality before the law).

c. Proses hukum berjalan sesuai dengan aturan yang telah ditetapkan (due process of law).

Sedangkan rechtsstaat adalah konsep negara hukum yang dikemukakan oleh Julius Stahl dengan karakteristik sebagai berikut:

a. Pengakuan dan perlindungan terhadap hak-hak asasi manusia (HAM).

b. Pemisahan kekuasaan negara berdasarkan teori Trias Politica.

c. Pemerintahan diselenggarakan berdasarkan undang-undang (wetmatig bestuur).

d. Eksistensi peradilan administrasi sebagai sarana perlindungan hukum bagi rakyat.

\section{Hak atas Upah}

Setiap pekerja berhak untuk memperoleh penghasilan agar dapat memenuhi penghidupan yang layak bagi kemanusiaan. Yang dimaksud dengan penghasilan yang dapat memenuhi 
penghidupan yang layak adalah jumlah penerimaan atau pendapatan pekerja dari hasil pekerjaannya sehingga mampu memenuhi kebutuhan hidup pekerja dan keluarganya secara wajar. Untuk mewujudkan penghasilan yang layak bagi kemanusiaan tersebut, pemerintah menetapkan kebijakan pengupahan yang melindungi pekerja.

Upah adalah hak pekerja yang diterima dan dinyatakan dalam bentuk uang sebagai imbalan yang diberikan oleh pengusaha selaku pemberi kerja kepada pekerja yang ditetapkan dan dibayarkan sesuai dengan perjanjian kerja, kesepakatan, atau peraturan perundang-undangan, termasuk di dalamnya tunjangan bagi pekerja dan keluarganya atas pekerjaan atau jasa yang telah dilaksanakan oleh pekerja.

Pengaturan pengupahan yang ditetapkan berdasarkan kesepakatan antara pekerja atau serikat pekerja dengan pengusaha selaku pemberi kerja tidak boleh lebih rendah dari ketentuan pengupahan yang telah ditetapkan dalam peraturan perundang-undangan bidang ketenagakerjaan yang berlaku. Dalam hal kesepakatan pengupahan lebih rendah nilainya atau bertentangan dengan peraturan perundang-undangan yang berlaku, maka kesepakatan tersebut harus dinyatakan batal demi hukum, dan pengusaha wajib membayar upah pekerja sesuai dengan peraturan perundang-undangan yang berlaku.

Sebagai jaring pengaman sosial (social safety net) pemerintah menetapkan upah minimum yang wajib dibayarkan oleh pengusaha selaku pemberi kerja kepada pekerjanya. Pemerintah menetapkan upah minimum berdasarkan kebutuhan hidup layak dan dengan memperhatikan produktivitas dan pertumbuhan ekonomi. Penetapan upah minimum oleh pemerintah diarahkan kepada pencapaian kebutuhan hidup layak (KHL). Setiap penetapan upah minimum harus disesuaikan dengan tahapan pencapaian kebutuhan hidup layak. Upah minimum dapat ditetapkan berdasarkan wilayah atau berdasarkan sektor pada wilayah provinsi atau kabupaten / kota. Upah minimum sektoral dapat ditetapkan untuk kelompok lapangan usaha berdasarkan klasifikasi lapangan usaha dan tidak boleh lebih rendah dari upah minimum regional daerah yang bersangkutan.

Apabila upah minimum sudah ditetapkan oleh pemerintah maka pengusaha selaku pemberi kerja dilarang membayar upah kepada pekerjanya lebih rendah dari upah minimum yang sudah ditetapkan. Bagi pengusaha yang tidak mampu untuk membayar upah minimum kepada pekerjanya sesuai dengan yang telah ditetapkan oleh pemerintah maka dapat dilakukan penangguhan pelaksanaan upah minimum. Penangguhan pelaksanaan upah minimum bagi perusahaan yang tidak mampu membayarnya dimaksudkan untuk membebaskan perusahaan yang bersangkutan untuk melaksanakan 
upah minimum yang berlaku dalam kurun waktu tertentu. Apabila kurun waktu penangguhan telah berakhir maka perusahaan yang bersangkutan wajib melaksanakan upah minimum yang berlaku pada saat itu tanpa berkewajiban untuk membayar kekurangan upah minimum pada kurun waktu penangguhan.

Di tingkat perusahaan, pengusaha memiliki kewajiban untuk menyusun struktur dan skala upah dengan memperhatikan golongan, jabatan, masa kerja, pendidikan, dan kompetensi. Penyusunan struktur dan skala upah dimaksudkan untuk menjadi pedoman penetapan upah di tingkat perusahaan, sehingga ada kepastian struktur dan skala pengupahan dan juga dapat mengurangi kesenjangan antara upah terendah dan upah tertinggi di tingkat perusahaan.

Pengusaha selaku pemberi kerja memiliki kewajiban untuk melakukan peninjauan terhadap upah pekerjanya secara berkala dengan memperhatikan kemampuan perusahaan dan produktivitas pekerja. Peninjauan upah secara berkala bertujuan untuk menyesuaikan dengan perkembangan harga kebutuhan hidup, prestasi kerja, dan kemampuan perusahaan.

Pada umumnya dalam pengupahan berlaku prinsip 'no work no pay', yang artinya tidak ada upah tanpa bekerja. Akan tetapi di dalam Undang-undang Ketenagakerjaan diatur beberapa pengecualian dari prinsip tersebut. Pengusaha tetap berkewajiban membayar upah dalam hal pekerja tidak dapat melakukan pekerjaannya yang disebabkan oleh pekerja sakit, pekerja meninggalkan pekerjaan karena menjalankan ibadah atau tugas negara, pekerja menikah, melahirkan, menikahkan, dan seterusnya.

Dalam hal perusahaan dinyatakan pailit atau dilikuidasi berdasarkan peraturan perundang-undangan yang berlaku maka upah dan hak-hak normatif pekerja lainnya merupakan hutang yang didahulukan pembayarannya. Pengusaha selaku pemberi kerja karena kesengajaan atau kelalaiannya mengakibatkan keterlambatan pembayaran upah dikenakan denda sesuai persentase tertentu dari upah pekerja yang diatur dalam peraturan perundang-undangan. Runtutan pembayaran upah pekerja dan segala pembayaran yang timbul dari hubungan kerja menjadi kadaluwarsa setelah melampaui jangka waktu 2 (dua) tahun sejak timbulnya hak.

Berdasarkan peraturan perundang-undangan ketenagakerjaan yang berlaku di Indonesia, maka ditemukan prinsip-prinsip hukum pengupahan sebagai berikut: 
a. Hak atas upah timbul pada saat dimulainya hubungan kerja dan berakhir pada saat terputusnya hubungan kerja (Pasal 2 Peraturan Pemerintah Nomor 8 Tahun 1981 tentang Perlindungan Upah).

b. Pengusaha selaku pemberi kerja dilarang melakukan diskriminasi dalam pengupahan bagi pekerja laki-laki dan pekerja perempuan yang melakukan pekerjaan yang sama (Pasal 3 Peraturan Pemerintah Nomor 8 Tahun 1981 tentang Perlindungan Upah).

c. Pengusaha selaku pemberi kerja yang mempekerjakan pekerja melebihi waktu kerja wajib membayar upah kerja lembur (Pasal 85 ayat (3) Undang-Undang Ketenagakerjaan).

d. Pengusaha selaku pemberi kerja yang mempekerjakan pekerja pada hari libur resmi wajib membayar upah kerja lembur (Pasal 85 ayat (3) Undang-Undang Ketenagakerjaan).

e. Pengusaha selaku pemberi kerja dilarang membayar upah lebih rendah dari ketentuan upah minimum (Pasal 90 ayat (1) Undang-Undang Ketenagakerjaan).

f. Upah tidak dibayarkan apabila pekerja tidak melakukan pekerjaannya (Pasal 93 ayat (1) Undang-Undang Ketenagakerjaan).

g. Komponen upah terdiri dari upah pokok dan tunjangan tetap dengan ketentuan upah pokok minimal 75\% dari jumlah upah pokok dan tunjangan tetap (Pasal 94 Undang-Undang Ketenagakerjaan).

h. Pelanggaran yang dilakukan oleh pekerja karena kesengajaan atau kelalaiannya dapat dikenakan denda (Pasal 95 ayat (1) Undang-Undang Ketenagakerjaan).

i. Pengusaha selaku pemberi kerja yang karena kesengajaan atau kelalaiannya mengakibatkan keterlambatan pembayaran upah dikenakan denda sebesar persentase tertentu dari upah yang diterima pekerja (Pasal 95 ayat (2) UndangUndang Ketenagakerjaan).

j. Dalam hal perusahaan dinyatakan pailit atau dilikuidasi berdasarkan peraturan perundang-undangan yang berlaku maka upah dan hak-hak normatif lainnya dari pekerja merupakan hutang yang didahulukan pembayarannya (Pasal 95 ayat (4) Undang-Undang Ketenagakerjaan). 
k. Tuntutan pembayaran upah pekerja dan segala pembayaran yang timbul dari hubungan kerja menjadi kadaluwarsa setelah melampaui jangka waktu 2 (dua) tahun sejak timbulnya hak (Pasal 96 Undang-Undang Ketenagakerjaan).

\section{Hak atas Jaminan Sosial Tenaga Kerja}

Setiap pekerja beserta keluarganya berhak untuk memperoleh jaminan sosial tenaga kerja. Dewasa ini jaminan bagi pekerja di perusahaan diatur dalam Undang-Undang Nomor 3 Tahun 1992 tentang Jaminan Sosial Tenaga Kerja. Yang dimaksud dengan tenaga kerja adalah setiap orang yang mampu untuk melakukan pekerjaan baik di dalam maupun di luar hubungan kerja. Ada empat program jaminan sosial bagi tenaga kerja yang diatur dalam Undang-Undang tersebut yaitu jaminan kecelakaan kerja, jaminan hari tua, jaminan kematian, dan jaminan pelayanan kesehatan.

Jaminan kecelakaan kerja pertama kali diatur dalam Undang-Undang Nomor 33 Tahun 1977 tentang Asuransi Sosial Tenaga Kerja. Berdasarkan Undang-Undang tersebut pada prinsipnya pengusaha selaku pemberi kerja bertanggung jawab atas kecelakaan kerja yang menimpa pekerjanya.

Jaminan hari tua merupakan tabungan wajib yang dimaksudkan untuk memberikan bekal uang bagi pekerja pada hari tua. Jaminan hari tua pertama kali diatur dalam Peraturan Pemerintah Nomor 33 Tahun 1977 tentang Asuransi Sosial Tenaga Kerja. Jaminan hari tua tersebut dibayarkan sekaligus atau secara berkala kepada tenaga kerja yang sudah mencapai usia 55 tahun atau mengalami cacat tetap. Iuran untuk program jaminan hari tua ditanggung bersama oleh pekerja dan pengusaha selaku pemberi kerja.

Jaminan Pemeliharaan Kesehatan pertama kali diatur dalam Undang-Undang Nomor 33 Tahun 1977 tentang Asuransi Sosial Tenaga Kerja. Pemeliharaan kesehatan adalah upaya pencegahan dan penanggulangan gangguan kesehatan yang memerlukan pemeriksaan, pengobatan, dan perawatan. Yang berhak memperoleh pemeliharaan jaminan kesehatan adalah tenaga kerja beserta keluarganya.

Dengan berlakunya Undang-Undang Nomor 40 Tahun 22004 tentang Sistem Jaminan Sosial Nasional dan Undang-Undang Nomor 24 Tahun 2011 tentang Badan Penyelenggara Jaminan Sosial maka program jaminan sosial tenaga kerja (Jamsostek) menjadi satu kesatuan dengan sistem jaminan sosial nasional (SJSN). 


\section{Hubungan Kerja dalam Perspektif Ekonomi}

Perspektif pengusaha dalam melihat hubungan kerja adalah perspektif ekonomi. Berdasarkan asumsi terhadap hukum ketenagakerjaan maka perspektif pengusaha dalam melihat hubungan kerja dapat dikelompokkan ke dalam dua kelompok yang disebut sebagai neoclassical economic dan newinstitutional economic.

Penganut paham neoclassical economic berpandangan bahwa hukum merupakan tambahan beban bagi perusahaan oleh karenanya semakin sedikit intervensi hukum dalam hubungan kerja akan semakin baik, sebaliknya penganut paham newinstitutional economic berpandangan bahwa intervensi hukum dalam hubungan kerja akan memberikan manfaat bagi perusahaan.

Perbedaan pandangan dalam melihat peran hukum ketenagakerjaan dalam hubungan kerja dikemukakan oleh Davies sebagai berikut:

Very broadly, we can devide economists into two camps: 'neoclassical' and 'newinstitutional'. They differ as to the goals they are pursuing (what their ideal labour market would look like) and as to the assumptions they use in their analysis. Those in the neoclassical camp tend to be hostile to legal intervention, and those in the newinstitutional camp who argue that labour law can benefits workers, firms, and the economy as a whole. ${ }^{2}$

\section{Neoclassical Economics}

Dalam perspektif neoclassical economic, hak-hak normatif pekerja dipandang sebagai beban perusahaan. Jika hukum ketenagakerjaan memberikan kewajiban kepada pengusaha untuk memberikan suatu hak normatif kepada pekerja maka pengusaha akan memandangnya sebagai tambahan biaya. Akan tetapi jika hukum ketenagakerjaan memiliki aturan tentang pekerja dengan fleksibilitas hubungan kerja dengan hak-hak normatif pekerja yang lebih sedikit maka pengusaha akan memandangnya sebagai peluang bagi pengurangan biaya.

Penganut paham neoclassical economic mengemukakan bahwa ada 2 (dua) keuntungan utama yang dapat diperoleh jika menggunakan tenaga kerja dalam hubungan kerja yang fleksibel. Keuntungan yang pertama adalah pengusaha dapat memindahkan risiko usaha kepada tenaga kerja ketika terjadi penurunan usaha daripada harus menanggung risiko tersebut di pundaknya sendiri. Tenaga kerja dengan hubungan kerja tetap, dalam pandangan penganut paham neoclassical economic, akan menjadi beban

2 A.C.L. Davies, Perspective on Labour Law, Cambridge: Cambridge University Press, 2004, hlm. 25 
perusahaan karena tetap terus masuk kerja dan tetap terus menerima upah tanpa melihat apakah perusahaan sedang mengalami penurunan usaha maupun tidak.

Dengan mempekerjakan tenaga kerja dalam hubungan kerja tetap maka pengusaha mengambil risiko kemungkinan bahwa tenaga kerja tersebut tidak selalu melakukan pekerjaan. Beberapa bentuk fleksibilitas hubungan kerja dapat memindahkan risiko tersebut kepada tenaga kerja, misalnya pekerja harian lepas (casual worker) yang akan dipanggil untuk bekerja hanya jika tenaganya dibutuhkan. Pengusaha dapat menekan biaya karena tidak harus memberikan upah tenaga kerja ketika terjadi penurunan usaha.

Keuntungan yang kedua, pengusaha dapat menekan biaya tenaga kerja (labour costs) karena hak-hak normatif yang diterima pekerja dengan fleksibilitas hubungan kerja lebih sedikit apabila dibandingkan dengan hak-hak normatif yang diterima oleh pekerja dengan hubungan kerja tetap. Akan tetapi penganut paham new institutional economic menolak pandangan tersebut dengan argumentasi bahwa tenaga kerja akan menjadi lebih produktif apabila pengusaha selaku pemberi kerja menghormati hak-hak normatif pekerja dan memberikan keamanan dalam bekerja.

Dalam praktik tidak mungkin suatu perusahaan dikelola tanpa menggunakan pekerja tetap sama sekali. Apabila pengusaha menjalankan suatu perusahaan, tidak mungkin pengusaha tersebut 'merumahkan' semua pekerja ketika perusahaan sedang mengalami kondisi penurunan usaha. Konsumen akan kecewa jika tidak mendapatkan pelayanan sesuai dengan jam kerja yang sudah dijanjikan. Yang mungkin dilakukan adalah perusahaan memiliki tenaga kerja inti dalam hubungan kerja tetap, ditambah dengan pekerja cadangan dengan hubungan kerja yang fleksibel, yang masuk kerja hanya jika tenaganya dibutuhkan saja. Inilah yang di dalam literatur disebut dengan 'numerical flexibility' dimana perusahaan memiliki fleksibilitas di dalam menetapkan jumlah tenaga kerjanya sesuai dengan kebutuhan perusahaan.

Keuntungan yang dapat diperoleh pengusaha jika menggunakan tenaga kerja dengan hubungan kerja yang fleksibel adalah sebagaimana uraian berikut:

Writers in the neo classical economic tradition identify two main benefits to employers from using atypical workers. One is that the employer is able to shift the risk of a downturn in business to the workers instead of having to shoulder that risk itself. The others is that atypical workers do not qualify for many statutary employment rights, making them cheaper to hire. New institutional economist 
question the wisdom of both these strategies. They argue that individuals will be more productive if they have secure jobs and if their rights respected by their employer. ${ }^{3}$

\section{Newinstitutional Economics}

Berbeda halnya dengan perspektif newinstitutional economics, yang memandang bahwa hak-hak normatif yang diberikan kepada pekerja akan membuat pekerja menjadi lebih produktif karena membuat mereka merasa aman dalam bekerja dan merasa dihargai oleh perusahaan. Meskipun pemberian hak normatif pekerja menimbulkan biaya, tetapi akan mendatangkan keuntungan yang lebih besar bagi perusahaan dalam jangka panjang.

Penganut paham newinstitutional economic berpendapat bahwa hukum ketenagakerjaan memberikan manfaat bagi perusahaan sebagaimana uraian berikut:

Newinstitutionalist argue that the law can help to create this kind of relationship between a firm and its workers. One of the reasons why many workers leave their jobs is that they find it impossible to combine work with family responsibilities. The law may be able to adress this problem by requiring firms to allow parents to work from home or to provide them with time off work to del with family problems. These measures would encourage parents to stay in work and would help firms to recoup their training costs. Similarly, the firms might miss out on its employee's idea for innovations if it never talks to them. But if the law requires the firm to set up a work council or to recognise a trade unions, the law might provide a forum in which the employee are able to discuss their ideas with managements. ${ }^{4}$

\section{Hubungan Kerja dalam Perspektif Pembangunan}

Perspektif pemerintah dalam melihat hubungan kerja adalah perspektif pembangunan. Dalam perspektif pemerintah, fleksibilitas hubungan kerja merupakan kebutuhan dunia usaha dalam rangka menciptakan efisiensi perusahaan akan tetapi pelaksanaannya tidak boleh melanggar peraturan perundang-undangan yang memuat norma perlindungan hukum bagi tenaga kerja.

Hukum ketenagakerjaan dan pembangunan secara konseptual memiliki hubungan yang sangat erat. Secara tradisional, hukum ketenagakerjaan memiliki fungsi perlindungan hukum bagi pekerja dengan menetapkan standar perlindungan tenaga kerja dan standar minimum kebutuhan hidup layak bagi pekerja. Di samping itu, terdapat fungsi lain yang erat kaitannya dengan pembangunan, yaitu fungsi hukum ketenagakerjaan untuk menciptakan kerangka kerja sama yang harmonis di antara para pelaku hubungan

J. Atkinson, Flexibility Uncertainty Manpower, Oxford: Oxford Journals of Legal Studies, 2004, hlm. 353

4 A.C.L. Davies, Op.Cit., hlm. 29 
industrial yang terdiri dari pekerja atau serikat pekerja, pengusaha atau organisasi pengusaha, dan pemerintah guna mewujudkan kesejahteraan bersama.

Dalam kebijakan fleksibilitas pasar tenaga kerja, kepentingan pembangunan sering kali menjadi lebih dominan sehingga menempatkan hukum ketenagakerjaan menjadi sarana untuk mencapai tujuan efisiensi ekonomi, sebagaimana diuraikan dalam paparan berikut ini:

These 'competing conceptions' of labour law to protect the fundamental social and economic rights of the workers on the one hand, and on the other to promote economic efficiency have often ended to the benefit of the latter. It is evident that labour law has often been used as a tool to restrict the freedom of workers furthering managerial rights and investment interest. 5

Perkembangan ekonomi dan kemajuan teknologi yang begitu pesat berdampak pada persaingan usaha yang semakin ketat. Dunia usaha yang semakin kompetitif menuntut pengusaha untuk adaptif terhadap kebutuhan pasar. Berdasarkan latar belakang tersebut, dalam pandangan pemerintah, dapat dimengerti bila dunia usaha membutuhkan fleksibilitas hubungan kerja guna meningkatkan efisiensi perusahaan.

Undang-Undang Ketenagakerjaan menyatakan bahwa pembangunan ketenagakerjaan bertujuan untuk meningkatkan kualitas tenaga kerja dan meningkatkan perlindungan bagi pekerja sesuai dengan harkat dan martabat kemanusiaan. Perlindungan terhadap tenaga kerja dimaksudkan untuk menjamin hak-hak dasar pekerja dengan tetap memperhatikan kemajuan dunia usaha. Tenaga kerja mempunyai peranan dan kedudukan yang penting sebagai pelaku sekaligus tujuan dari pembangunan.

Undang-Undang Ketenagakerjaan menyatakan bahwa pembangunan ketenagakerjaan bertujuan untuk:

a. Memberdayakan dan mendayagunakan tenaga kerja secara optimal dan manusiawi.

b. Mewujudkan pemerataan kesempatan kerja dan penyediaan tenaga kerja yang sesuai dengan kebutuhan pembangunan.

c. Memberikan perlindungan kepada tenaga kerja.

d. Mewujudkan kesejahteraan tenaga kerja.

Ruang lingkup pembangunan ketenagakerjaan meliputi bidang-bidang perencanaan ketenagakerjaan, informasi ketenagakerjaan. pelatihan ketenagakerjaan,

5 Surya Tjandra, Labour Law and Development in Indonesia, Leiden: Leiden University Repository, 2016, hlm. 3 
penempatan tenaga kerja, perluasan kesempatan kerja, dan penggunaan tenaga kerja asing. Perencanaan ketenagakerjaan adalah proses penyusunan rencana ketenagakerjaan secara sistematis yang dijadikan sebagai dasar dan acuan dalam penyusunan kebijakan, strategi, dan pelaksanaan program pembangunan yang berkesinambungan. Perencanaan ketenagakerjaan disusun atas dasar informasi ketenagakerjaan yang antara lain meliputi informasi penduduk dan tenaga kerja, kesempatan kerja, pelatihan kerja, produktivitas tenaga kerja, kondisi lingkungan kerja, pengupahan, kesejahteraan tenaga kerja, dan jaminan sosial tenaga kerja.

Pelatihan kerja diselenggarakan dan diarahkan untuk membekali, meningkatkan, dan mengembangkan kompetensi kerja, guna meningkatkan produktivitas, dan kesejahteraan pekerja. Pelatihan kerja dapat diselenggarakan dengan sistem pemagangan. Pemagangan merupakan bagian dari sistem pelatihan kerja yang diselenggarakan secara terpadu antara pelatihan di lembaga pelatihan kerja dengan bekerja secara langsung di bawah bimbingan dan pengawasan dalam proses produksi barang dan jasa di perusahaan. Pemagangan dilakukan atas dasar perjanjian pemagangan yang dibuat secara tertulis antara peserta pemagangan dengan perusahaan. Perjanjian pemagangan sekurangkurangnya memuat hak dan kewajiban peserta pemagangan dan perusahaan serta jangka waktu pemagangan. Peserta yang sudah mengikuti program pemagangan berhak atas pengakuan kualifikasi kompetensi kerja dari perusahaan atau lembaga sertifikasi.

Pelayanan penempatan tenaga kerja merupakan kegiatan untuk mempertemukan tenaga kerja dengan perusahaan pemberi pekerjaan sehingga tenaga kerja memperoleh pekerjaan yang sesuai dengan minat dan kemampuannya sementara perusahaan pemberi pekerjaan dapat memperoleh tenaga kerja sesuai dengan kebutuhannya.

\section{Legislasi Ketenagakerjaan}

Di dalam Burgelijk Wetboek (BW), norma hukum yang mengatur tentang ketenagakerjaan terdapat di dalam buku III, bab 7A, yang terdiri dari bagian pertama mengenai ketentuan umum yang termuat dalam Pasal 1601a sampai dengan Pasal 1601c, bagian kedua tentang perjanjian perburuhan pada umumnya yang termuat dalam Pasal 1601d sampai dengan Pasal 1601x, bagian ketiga tentang kewajiban majikan yang termuat dalam Pasal 1602a sampai dengan Pasal 1602z, bagian keempat tentang kewajiban buruh yang termuat dalam Pasal 1603a sampai dengan Pasal 1603d, bagian kelima tentang cara-cara berakhirnya hubungan kerja yang berasal dari perjanjian yang termuat dalam Pasal 1603e sampai 
dengan Pasal 1603w, dan ketentuan penutup yang termuat dalam Pasal 1603x sampai dengan Pasal 1603z.

Apabila hubungan kerja diserahkan sepenuhnya kepada para pihak untuk mengaturnya maka dapat terjadi ketimpangan karena perbedaan bargaining position dari para pihak dalam hubungan kerja. Oleh karena itu diperlukan peran afirmatif dari pemerintah melalui legislasi bidang ketenagakerjaan yang memberikan perlindungan hukum bagi pekerja.

\section{Pengawasan Ketenagakerjaan}

Pengawasan ketenagakerjaan (labour inspection) adalah kegiatan untuk mengawasi dan menegakkan pelaksanaan peraturan perundang-undangan bidang ketenagakerjaan. Pengawasan ketenagakerjaan memiliki fungsi yang penting dalam penegakan hukum ketenagakerjaan dan perlindungan hukum bagi tenaga kerja.

Ruang lingkup pengawasan ketenagakerjaan meliputi pengawasan terhadap pelaksanaan peraturan perundang-undangan bidang ketenagakerjaan, dan identifikasi permasalahan di bidang ketenagakerjaan. Tugas pengawasan ketenagakerjaan dilaksanakan oleh Menteri Tenaga Kerja dengan mengangkat pegawai pengawas ketenagakerjaan yang diberikan kewenangan untuk menjalankan tugas pengawasan ketenagakerjaan.

Pengawasan ketenagakerjaan dapat dilaksanakan melalui dua pendekatan yaitu pendekatan preventif dan pendekatan represif tergantung dari tingkat kepatuhan masyarakat dalam melaksanakan hukum ketenagakerjaan. Pendekatan preventif dilakukan untuk mencegah terjadinya pelanggaran hukum ketenagakerjaan dengan membangkitkan kesadaran dari masyarakat untuk melaksanakan hukum ketenagakerjaan. Sedangkan pendekatan represif dilakukan untuk menghentikan pelanggaran hukum ketenagakerjaan melalui upaya paksa.

Pengawasan ketenagakerjaan dilakukan oleh pegawai pengawas ketenagakerjaan yang mempunyai kompetensi dan independensi untuk menjamin pelaksanaan peraturan perundang-undangan bidang ketenagakerjaan. Yang dimaksud dengan kompetensi adalah kecakapan untuk melaksanakan tugas pengawas ketenagakerjaan, sedangkan yang dimaksud dengan independensi adalah dalam hal mengambil suatu keputusan pegawai pengawas ketenagakerjaan tidak dipengaruhi oleh pihak mana pun. Pegawai pengawas ketenagakerjaan ditetapkan oleh Menteri Tenaga Kerja. Pegawai pengawas 
ketenagakerjaan dalam melaksanakan tugasnya memiliki kewajiban untuk merahasiakan segala sesuatu yang menurut sifatnya wajib dirahasiakan dan tidak menyalahgunakan kewenangan yang diberikan kepadanya.

Tahapan dalam pelaksanaan pengawasan ketenagakerjaan adalah sebagai berikut:

1. Tahap sosialisasi norma hukum ketenagakerjaan kepada masyarakat dengan tujuan agar masyarakat memiliki pemahaman dan kesadaran dalam melaksanakan peraturan perundang-undangan di bidang ketenagakerjaan.

2. Tahap pembinaan melalui pemeriksaan dan pemberian peringatan dalam bentuk nota pengawasan apabila ditemukan pelanggaran terhadap peraturan perundang-undangan bidang ketenagakerjaan.

Tahap penegakan hukum melalui penyidikan oleh penyidik pegawai negeri sipil apabila ditemukan tindak pidana ketenagakerjaan.

\section{KESIMPULAN}

Perspektif pekerja dalam melihat hubungan kerja adalah perspektif hak asasi manusia (HAM). Dalam perspektif pekerja, pemenuhan hak asasi manusia hendaknya diberikan kepada semua pekerja tanpa membedakan pekerja dengan hubungan kerja tetap atau pekerja dengan fleksibilitas hubungan kerja. Dua jenis hak sipil dan politik yang relevan dengan hubungan kerja adalah hak berserikat bagi pekerja dan hak non diskriminasi. Jenis hak sosial, ekonomi, dan budaya yang relevan dengan hubungan kerja adalah hak atas pekerjaan, hak atas upah, dan hak atas kesehatan dan keselamatan kerja.

Perspektif pengusaha dalam melihat hubungan kerja adalah perspektif ekonomi. Berdasarkan asumsi terhadap hukum ketenagakerjaan maka perspektif pengusaha dalam melihat hubungan kerja dapat dikelompokkan ke dalam dua kelompok yang disebut sebagai neoclassical economic dan newinstitutional economic. Penganut paham neoclassical economic berpandangan bahwa hukum merupakan tambahan beban bagi perusahaan oleh karenanya semakin sedikit intervensi hukum dalam hubungan kerja akan semakin baik, sebaliknya penganut paham newinstitutional economic berpandangan bahwa intervensi hukum dalam hubungan kerja akan memberikan manfaat bagi perusahaan.

Perspektif pemerintah dalam melihat hubungan kerja adalah perspektif pembangunan. Dalam perspektif pemerintah, fleksibilitas hubungan kerja merupakan kebutuhan dunia usaha dalam rangka menciptakan efisiensi perusahaan akan tetapi pelaksanaannya tidak boleh melanggar peraturan perundang-undangan yang memuat 
norma perlindungan hukum bagi tenaga kerja. Hukum ketenagakerjaan dan pembangunan secara konseptual memiliki hubungan yang sangat erat. Secara tradisional, hukum ketenagakerjaan memiliki fungsi perlindungan hukum bagi pekerja dengan menetapkan standar perlindungan tenaga kerja dan standar minimum kebutuhan hidup layak bagi pekerja. Di samping itu, terdapat fungsi lain yang erat kaitannya dengan pembangunan, yaitu fungsi hukum ketenagakerjaan untuk menciptakan kerangka kerja sama yang harmonis di antara para pelaku hubungan industrial yang terdiri dari pekerja atau serikat pekerja, pengusaha atau organisasi pengusaha, dan pemerintah guna mewujudkan kesejahteraan bersama. Dalam kebijakan fleksibilitas pasar tenaga kerja, kepentingan pembangunan sering kali menjadi lebih dominan sehingga menempatkan hukum ketenagakerjaan menjadi sarana untuk mencapai tujuan efisiensi ekonomi.

\section{Daftar Pustaka}

A.C.L. Davies, Perspective on Labour Law, Cambridge: Cambridge University Press, 2004.

Davidov, Guy, and Brian Langille, Boundaries and Frontiers of Labour Law, The Hague: Kluwer Law International, 2000.

Davies, Paul, and Mark Freedland, Kahn-Freund's Labour and The Law, London: Stevens \& Sons Ltd., 1993.

Deakin, Simon, and Frank Wilkinson, The Law of the Labour Market, Oxford: Oxford University Press, 2005.

J. Atkinson, Flexibility Uncertainty Manpower, Oxford: Oxford Journals of Legal Studies, 2004.

Tjandra, Surya, Labour Law and Development in Indonesia, Leiden: Leiden University Repository, 2016.

Van Voss, Heerma, dan Surya Tjandra, Bab-Bab tentang Hukum Perburuhan Indonesia, Denpasar: Pustaka Larasati, 2012.

Veneziani, Bruno, The Evolution Contract of Employment, London: Mansell Publishing Ltd., 1986.

Wedderburn, Lord, Labour Law and Industrial Relations: Building on Kahn-Freund, Oxford: Clarendon Press, 2003.

Wheelwright, Karen, Labour Law, Sydney: Butterworths, 1999. 